\title{
Ricardo Dolmetsch
}

\begin{abstract}
Ricardo Dolmetsch is a neurobiologist at Stanford University, California. In March he announced his affiliation with the Allen Institute for Brain Science in Seattle, Washington, where he will help to develop tools for identifying the genetic mutations that alter brain development and behaviour.
\end{abstract}

Did you always know you would be a scientist? No. I grew up in Colombia in a family of artists. I became enamoured with science in a bizarre way: I was suspended from school for writing erotic poems in typing class and, made to stay at home for a week, I learned how to cook. I realized then that I was good at following instructions and doing manual tasks, which is a big part of being a scientist.

What piqued your interest in neurobiology? When I decided I wanted to go to university in the United States, I knew very little about the universities there. I got accepted to Brown University in Providence, Rhode Island. Alongside my studies, I worked as a laboratory assistant for a clinician who was the head of child neurology at Rhode Island Hospital in Providence. She had lots of equipment, a technician and me. It was great. I got to work with microscopes, oscilloscopes and amplifiers, and this made me realize that I wanted to go to graduate school.

\section{You had a difficult start to your PhD programme. What happened?}

I applied to Stanford University, in part because I enjoyed my interview with the neurobiologist Carla Shatz during the pre-application process. But, as soon as I got there, she left. I joined another lab, but the principal investigator there, neuroscientist Dennis Choi, left four months later. I thought I was the kiss of death for faculty at Stanford. I was not born in the United States, so, at the time, I was not eligible for US National Institutes of Health (NIH) funding. I had to either find a new lab and funding quickly, or go back to Colombia and join the army, which, in those days, was not a fabulous option. A faculty member at Stanford suggested that I find a supervisor who was just starting their lab. I found molecular biologist Richard Lewis. Although Lewis was not a neuroscientist, he was exploring how calcium channels regulate immune function. I became his first student and, after four years and two failures, I made a machine that could control intracellular calcium patterns in cells, which led to several high-profile papers.

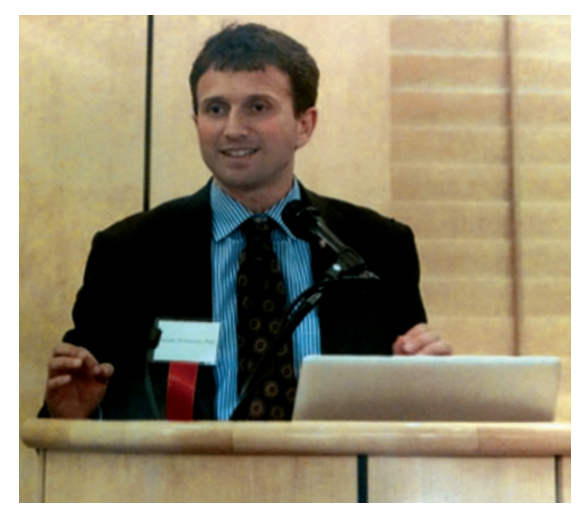

What was your experience of being a new faculty member at Stanford?

It can be difficult for young professors to begin with. Suddenly there are all these things to do so that you can execute your good ideas managing and motivating people, or looking after the finances. Initially, things went pretty well. But the lab started running out of money and the situation became desperate. Then my son was diagnosed with autism, which proved to be pivotal. For the first time, I made a conscious decision to focus my career on neurodevelopmental diseases - genetic diseases, including autism, that affect cognition. To support the change in my research focus, I began to apply for big, competitive grants and, luckily, I got an NIH Pioneer award. This rescued the lab and has allowed me to stay in this area of work.

Is the position at the Allen Institute motivated by aspirations to set up a lab in Colombia?

That is one part of it. I hope to learn how to secure sustainable funding, manage people and direct a big project. I feel I owe something to the community back home that invested in my success - so, yes, at some point, I would love to start a research institute in Colombia. But until more research funding becomes available there, it is not realistic. For now, I will retain a lab at Stanford as a way to use the tools developed at the Allen Institute.

\section{INTERVIEW BY VIRGINIA GEWIN}

\section{CORRECTION}

The News item 'Career-path support' (Nature 485, 139; 2012) wrongly located the Educational Testing Service in Washington DC instead of Princeton, New Jersey.

\section{PAY GAP}

\section{Reaching higher ranks}

Full-time male Canadian faculty members earned almost $13 \%$ more than their female counterparts during the 2010-11 academic year, according to a 3 May report by Statistics Canada, a federal agency in Ontario. Women earned, on average, Can $\$ 106,970$ (US\$105,921) in 2010-11 compared with an average of $\$ 120,378$ for men, the report says. For full professors, the report notes that females earned $5 \%$ less than males that year. Women have been slower to reach the highest academic ranks, and have not yet attained the salary levels of their longer-tenured male faculty members, says sociologist Michael Smith at McGill University in Montreal, Canada, who studies labour market and economic issues. Women account for just $23.4 \%$ of full professors, but $46.4 \%$ of assistant professors.

\section{EDUCATION}

\section{Best global provider}

The US higher-education system tops a list of 48 countries in a ranking released on 10 May. Authors compiled the list from data on resources, output, connectivity and environment for Universitas 21, an international network of research universities based in Birmingham, UK. Co-author Ross Williams, professorial fellow at the Melbourne Institute of Applied Economic and Social Research in Australia, says that the list can guide early-career researchers to the higher-ranking nations that are more likely to provide the funding, positive environment and peer interaction needed for career advancement.

\section{NEUROSCIENCE}

\section{Brain research boost}

A six-year, Can\$100-million (US\$99-million) commitment from the Canadian federal government to fund neuroscience research will include training awards for early-career neuroscientists. The Canada Brain Research Fund will award a number of postdoctoral fellowships at $\$ 50,000$ per year and $\mathrm{PhD}$ studentships at $\$ 25,000$ per year, which will also be open to international students who are accepted at a Canadian university. The Brain Canada Foundation in Montreal, a national charity, will administer the awards. The foundation will aim to match the government funding through private donors and organizations. The number of postdoc fellowships and studentships will be determined once matching funds are tallied. 